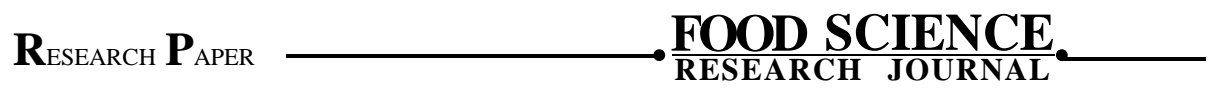
e ISSN-2230-9403 - Visit us : www. researchjournal.co.in Volume 8 | Issue 1 |April, $2017 \mid$ |128-131 DOI : 10.15740/HAS/FSRJ/8.1/128-131

\title{
Effects of processing on phytic acid, iron and its bioavailability of Macrotyloma uniflorum
}

\author{
Vishakha Sharma and Vibha Bhatnagar
}

\begin{abstract}
Horse gram is one of the inexpensive sources of protein, calcium and iron. Simple processing such as germination and roasting of horse gram were used to reduce the anti-nutritional factors. The germination was carried out by washing, soaking $(8 \mathrm{~h})$, germination period $(48 \mathrm{~h})$, and oven drying $\left(50^{\circ} \mathrm{C}\right)$ and ground into flour in grinder. In another processing method the horse gram was roasted for 10 minutes on low flame, cooled and powdered. Result of the present study revealed that germination and roasting have good effects on increasing in vitro iron bioavailability. While anti-nutritional factor phytates also reduced on both processing. The content of iron was also increases after germination and roasting as compared to untreated horse gram flour.
\end{abstract}

Key Words : Horse gram, Germination, Roasting, Iron, Anti-nutritional

How to cite this article : Sharma, Vishakha and Bhatnagar, Vibha (2017). Effects of processing on phytic acid, iron and its bioavailability of Macrotyloma uniflorum. Food Sci. Res. J., 8(1): 128-131, DOI : 10.15740/HAS/FSRJ/8.1/128-131.

VISHAKHA SHARMA, Department of Foods and Nutrition, College of Home Science, Maharana Pratap University of Agriculture and Technology, UDAIPUR (RAJASTHAN) INDIA

Email : sharmavishakha19@gmail.com

Associate Authors' :

VIBHA BHATNAGAR, Department of Foods and Nutrition, College of Home Science, Maharana Pratap University of Agriculture and Technology, UDAIPUR (RAJASTHAN) INDIA 